\title{
Three discomycetous genera new to Finland
}

\author{
Yrjö Mäkinen and Aira Pohjola \\ Department of Botany, University of Turku, Turku 2, Finland
}

The discomycetous flora of Finland is very poorly known. Since Karsten's publications on the subject, only a few short papers have appeared, although some additional records have been published, mainly in fungus floras dealing with basidiomycetes. Few of these include species of the family Humariaceae sensu Dennis (1968), or Pyronemaceae sensu ECKBLAD (1968). It is not surprising, therefore, that numerous new species and a few genera new to Finland have been discovered during our recent studies on the distribution of the operculate discomycetes in Finland. Three genera new to Finland, Nannfeldtiella, Melastiza, and Sepultaria, are now reported.

The measurements refer to dry material warmed in lactophenol.

1. Nannfeldtiella. The genus was erected by Eckblad (1968, p. 116) for a peculiar small dark discomycete, always occurring in association with Octospora aggregata. The only species of the genus, $N$. aggregata Eckbl., is a spring fungus found, according to EcKBLAD (p. 119), «at places where Alces has been staying «. The type locality is in Buskerud in S Norway, but the species has been collected in several localities in both Norway and Sweden. Eakblad places the genus in the Sarcoscyphaceae.

The first of our finds of Nannfeldtiella aggregata in Finland was in SW Finland, Paimio, $2 \mathrm{~km}$ E of the Vartsala road junction, along the highway no. 4, where it was found on May 8, 1965 (Yrjö Mäkinen; TUR). The locality was a dry pine heath, and a search revealed three adjacent occurrences of Octospora aggregata, all apparently in places with elk excrements (but not on the dung). Two of these also had apothecia of $N$. aggregata, growing intimately intermixed with those of $O$. aggregata, and on the white subiculum of that fungus. The fungi were partly growing on mosses, partly on the twigs and old leaves of Calluna vulgaris lying on the ground. Another collection came from SE Finland, Virolahti, Kurkela (May 12, 1966, by Timo Kurkela; HFR); both species occurred on decaying birch leaves, on twigs of Calluna, and on mosses. A further collection was made by Mauno Yli-Pietilä in N Finland, Rovaniemi rural commune, Pisavaara (May 26, 1968; TUR); both O. aggregata and $N$. aggregata were growing on decaying leaves of Salix myrsinifolia, Betula pubescens and Poa pratensis ssp. alpigena. At the time of collecting, the surroundings were still snowcovered. The spores of the Paimio collection measure $17.21 \pm 0.12 \mu$ in length and 8.61 $\pm 0.12 \mu$ in breadth, those of the Pisavaara collection $17.37 \pm 0.14 \mu$ in length and 8.53 $\pm 0.14 \mu$ in breadth. These measurements fit very well with those given by ECKBLAD (1968). The asci of the Virolahti specimens are not mature enough to allow exact spore measurements.

N. aggregata (and O. aggregata) are certainly not very rare in Finland, but owing to their early occurrence in the spring, they tend to escape observation. Subsequent examination revealed the following additional localities: U, Espoo (C. Tigerstedt 1908; H), Helsinki (R. Tuomikoski 1960; H); EH, Kuhmoinen (H. Harmaja 1968; H), Urjala (T. Brander 1960; H) ; PH, Ähtäri (P. \& I. 

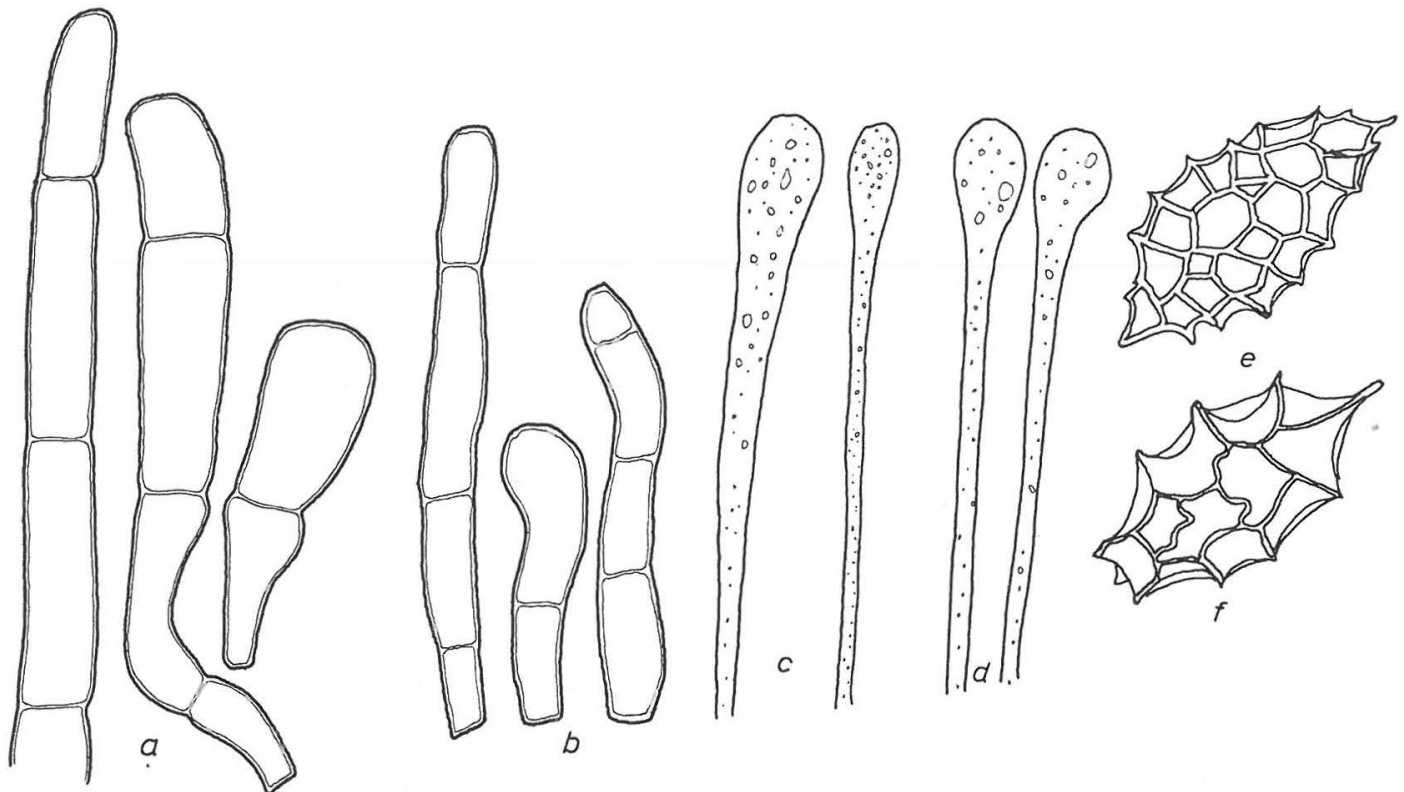

Fig. 1. Hairs (a, b), paraphyses (c. d) and spore (e, f) of Aleuria aurantia (a, c, f) and Melastiza chateri (b, d, e), a-d 590x; e, f $1810 x$.

Kytövuori 1966; H) ; Ks, Kuusamo (H. Harmaja 1968; H). A detailed list of localities will be given in another connection.

2. Melastiza. The first specimen of $M$. chateri (W. G. Smith) Boud. was collected by P. A. Karsten as long ago as 1891 under the name Peziza laetissima Karst. in Mustiala, Tammela, S Finland. In 1946, J. A. Nannfeldt checked the identification of this specimen with $M$. chateri (the specimen is preserved in UPS). Superficially, $M$. chateri greatly resembles a small Aleuria aurantia, and often occurs in similar places, and in company with it. $M$. chateri is somewhat darker and brownish red (but a yellowish form also occurs, collected in Toivakka in Central Finland). The only marked microscopic difference is in the nature of the hairs (Fig. $1 \mathrm{a}, \mathrm{b}$ ), which are very sparse and hyaline in Aleuria (which is often considered to have no hairs at all), but much more frequent and clearly yellowish or brownish in Melastiza. This character is hardly sufficient to warrant the separation of the genera. The paraphyses of Melastiza are usually somewhat more swollen at the tips than those of Aleuria, or even clavate, but this character varies between wide limits (Fig. $1 \mathrm{c}, \mathrm{d}$ ). The elaborate spore ornamentation is very similar in the two species, and hardly any distinction can be made on this basis, although the meshes of Melastiza spores are somewhat smaller, and more regular than those of Aleuria (Fig. 1 e, f; cf. LE GAL 1947). The average length of the spores of $M$. chateri relative to their width is slightly greater, but this requires rather numerous measurements.

$M$. chateri was first collected by us in N Finland, Rovaniemi rural commune, Käyrämö, on moist clayey roadside waste ground at the Pekkala Ciafé, on Aug. 23, 1965 (Yrjö Mäkinen; TUR). The spores (sculpturing included) measure $(\mathrm{n}=100) 20.96 \pm 0.21$ $\times 10.64 \pm 0.11 \mu$, the asci $(\mathrm{n}=20) 280.4$ $\pm 2.5 \times 12.63 \pm 0.24 \mu$, and the hairs $(\mathrm{n}=$ 20) $94.9 \pm 6.2 \times 9.72 \pm 0.32 \mu$. The species has later been collected in a number of localities all over Finland; a detailed list of localities will be given in another connection. Another specimen, collected in S Finland, Tammela, Saari Park, yard of the «LounaisHämeen Pirtti«, on decaying plant debris on sandy ground (July 8, 1967, by Aira Pohjola), yielded the following measurements: spores $(\mathrm{n}=100) \quad 20.47 \pm 0.22 \times 10.30 \pm$ 0.13 , asci $(n=20) 232.5 \pm 3.0 \times 11.63 \pm$ $0.18 \mu$, hairs $(n=20) 102.4 \pm 12.4 \times 10.32$ $\pm 0.30 \mu$. The spores thus appear to be larger than those measured by EakBlad (1956) or GreLET (1942). The species is certainly not 


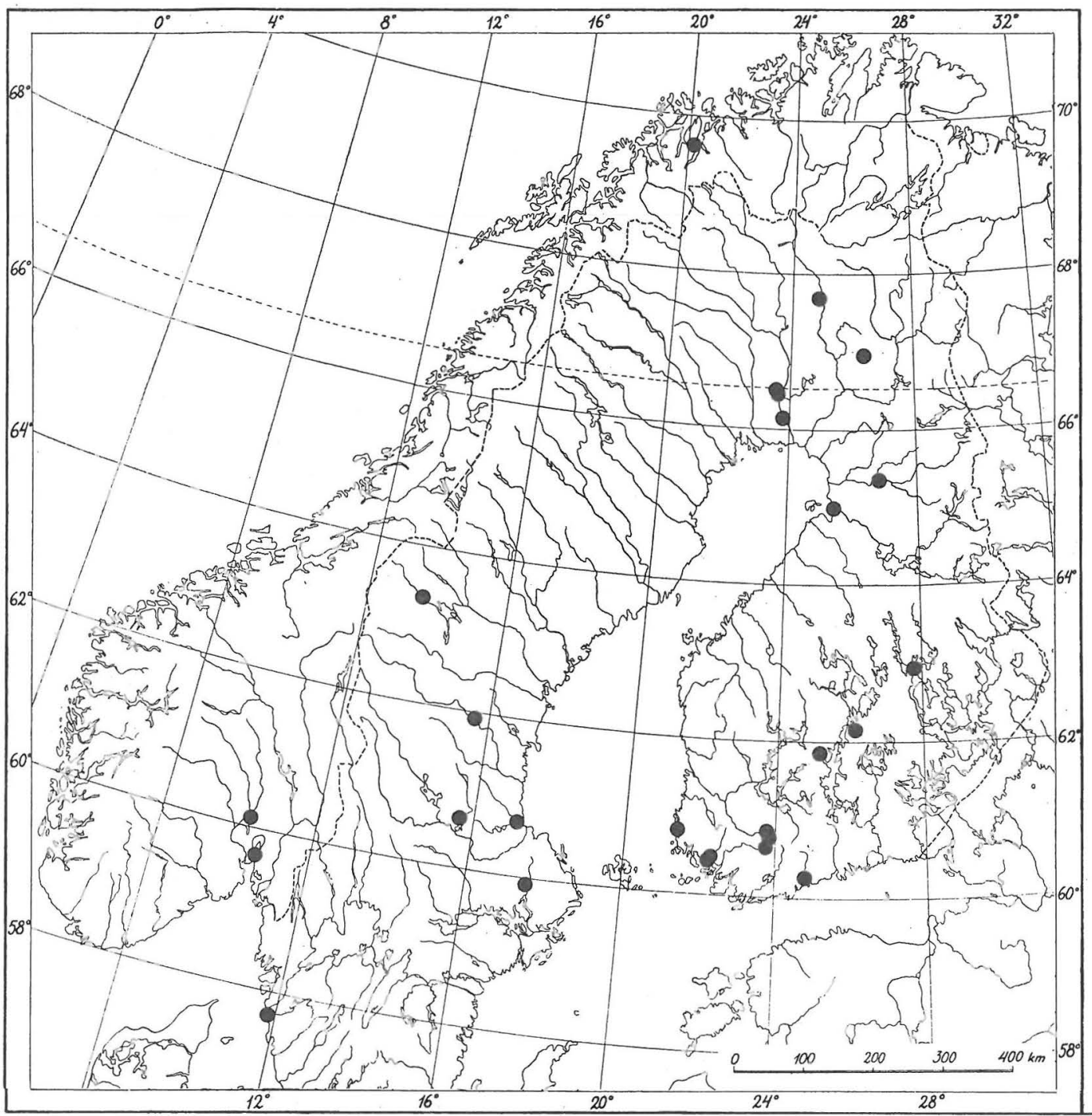

Fig. 2. Distribution of Melastiza chateri in Fennoscandia according to specimens in OULU, S, TROMS, TUR, UPS, and EGKBLAD (1956).

rare in Finland, but is apt to be overlooked and/or confused with Aleuria aurantia. Melastiza chateri often grows on clayey ground mixed with sand, especially on newly established sites. It has been found in several localities in Norway (Eckblad 1956; 1968, p. 69), and in Sweden it is apparently also widely distributed. The Norwegian and Swedish records, based on the specimens preserved in OULU, S, TROMS, TUR and UPS, have been marked on the map in Fig. 2 with the known Finnish localities.

3. Sepultaria. The first Finnish specimen of $S$. arenosa (Fuck.) Boud. was collected in Finnish Lapland, Utsjoki, Kevo, on the sandy shore of the lake Kevojärvi (Aug. 23, 1964, by Heli Heikkilä; TUR). The size of the apothecia varied from 4 to $5 \mathrm{~mm}$, the colour of the disc being grey with a tint of lilac, and of the outside brown, and the margin being somewhat crenate. The spores measure $(\mathrm{n}=$ 100) $22.08 \pm 0.13 \times 11.38 \pm 0.08 \mu$, and the asci $(n=20) 247.3 \pm 5.2 \times 13.94 \pm 0.32 \mu$. The spores correspond well with the values given by Densis (1968, p. 31), the asci being slightly larger. The second find was made in 
SW Finland, Turku, Kupittaa, between the streets Kiinamyllynkatu and Sirkkalankatu, on the site of an old woodyard (Oct. 30, 1967, by Aira Pohjola; TUR).

On native habitats $S$. arenosa is a typical dune species like the closely related $S$. arenicola (cf. Andersson 1950, p. 22); the Kevojärvi locality corresponds to the dune habitats. Another dune ascomycete found in the vicinity on the sandy shore of Kevojärvi is Corynetes arenarius (KALLIO \& KANKAINEN 1964, 1966). The Turku station is on ground very strongly modified by man; in Sweden, it also often occurs on similar sandy places, according to the specimens in S and UPS.

Acknowledgements. We are indebted to Dr. Harri Harmaja ( $\mathrm{H})$ for placing collections of Nannfeldtiella at our disposal.

\section{REFERENCES}

Andersson, O., 1950: Larger fungi on sandy grass heaths and sand dunes in Scandinavia. Bot. Not. Suppl. 2:2, 1-89.

Dennis, R. W. G., 1968: British ascomycetes. 455 pp. Stuttgart.

Egkblad, F.-E., 1956: Some operculate discomycetes new to Norway. - Friesia 5, 223230.

- 1968: The genera of the operculate discomycetes. A re-evaluation of their taxonomy, phylogeny and nomenclature. - Nytt Mag. Bot. 15, 1-191.

Grelet, L.-J., 1942: Les discomycètes de France d'après la classification de Boudier. 9. fasc. - Rev. Myc. 7, 3-26.

LE GaL, M., 1947: Recherches sur les ornementations sporales des discomycètes operculés. - Ann. Sci. Nat. 11, Bot. 8, 73-297.

Kallio, P. \& E. Kankainen, 1964: Notes on the macromycetes of Finnish Lapland and adjacent Finnmark. - Ann. Univ. Turku. A, II:32 (Rep. Kevo Subarctic Sta. 1), 178235.

- 1966: Additions to the mycoflora of northernmost Finnish Lapland. - Ann. Univ. Turku. A, II:36 (Rep. Kevo Subarctic Sta. 3), $177-210$. 